\title{
How Do Students at Median Graduate Economic Programs Differ from Students at Top-ranked Programs?
}

\author{
David Colander ${ }^{\mathrm{a}}$, Tiziana Dominguez ${ }^{\mathrm{a}}$, Gail Hoyt ${ }^{\mathrm{b}}$ and \\ KimMarie McGoldrick ${ }^{\mathrm{c}}$

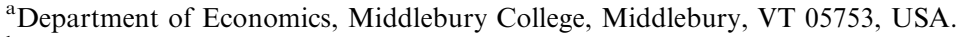 \\ ${ }^{\mathrm{b}}$ Department of Economics, University of Kentucky, Lexington, KY 40506, USA. \\ ${ }^{c}$ University of Richmond, Richmond, VA 23173, USA.
}

This paper reports the results of a survey of students at median economics graduate programs and compares it with the results of a survey of students at top economics graduate programs done by Colander. Overall, a study of the data shows that while there are some differences in the student views, there are large areas of similarity. Some of the particular findings are that there are more US respondents in median programs than in top programs, median students have more interest in econometrics, history of thought and economic literature than do students at top programs, although after the fifth year, their interest in any field drops significantly. Results also indicate that students at top schools are much more likely to be involved in writing scholarly papers, and that students at top schools give far less emphasis to excellence in mathematics as a path to the fast track than do students at median schools.

Eastern Economic Journal (2009) 35, 423-432. doi:10.1057/eej.2008.46

Keywords: graduate economic education; attitudes; views

JEL: A2

\section{INTRODUCTION}

Over the last 20 years, Colander [Colander and Klamer 1987; Colander 2005; 2006] has studied graduate economics education at top schools in the United States. Top economics programs are influential to the economics profession, but they are not the entire story. The top 15 programs grant about 30 percent of all US Ph.D.'s awarded each year [Hansen 1991], which means that the other more than $100 \mathrm{Ph}$.D. programs grant about 70 percent of the economics Ph.D.s. The goal of this paper is to consider the making of an economist at these other programs, which we will call median programs, and see how they differ from the making of an economist at the top programs studied previously by Colander.

The data for this study were collected through an online survey that duplicated most of the questions Colander asked students at top schools. ${ }^{1}$ The questions reported on here are a subset of a more extensive survey distributed to 131 schools across the United States. In this larger survey, 1,489 students from 106 schools completed the questionnaire, which from a total population of about 12,000 economics graduate students, generates a response rate of 12.6 percent. $^{2}$

In order to generate the subsample of median schools on which the comparison to Colander's previous work on top schools can be made, some ranking scheme must be utilized. Exactly what is considered a top and a median school is a continual subject of debate, especially at schools close to the top, but not counted as top, 
in a particular ranking. Because there are many different rankings, there are at least 20 and possibly 30 schools that consider themselves to be in the top 10 . However, for schools ranked 20 or below, it becomes harder and harder to make the case for a top school designation.

The National Research Council classifies programs by Tiers, with Tier 1 being the highest, and Tier 5 the lowest. Tier 1 programs produced an average of 22.3 Ph.D.'s per year over the 1970-1992 period. Tier 2 programs have produced on average 17.5 Ph.D.s per year, Tiers 3, 4 and 5 programs produced 9.25, 6.8, and 5.1 Ph.D.s, respectively [Scott and Anstine, 1997]. To determine the population of median schools we excluded all institutions ranked 25 or higher in Thursby [2000]. Thus, translated to National Research Council classifications, we have excluded all Tier 1 and Tier 2 schools and some Tier 3 programs. This leaves 75 programs from Tiers 3 , 4 , and 5, and 32 programs too small to make it into the NRC study. ${ }^{3}$

Of the population of 107 median programs, 86 participated in the survey, so the results presented here are for a subset of 86 "median" schools within the larger survey. Because the top 25 programs and five heterodox programs not included in our median designation are also the largest programs, we estimate that the percentage of median students is approximately 60 percent of the total population, or about 7,500 graduate students. We obtained responses from 742 students, suggesting a response rate of about 10 percent of the total number of students whom we have classified as median students. ${ }^{4}$ The distribution of the sample by year was 24 percent for first year students, 25 percent for second, 19 percent for third, 15 percent for fourth, and 16 percent for fifth year and beyond, which is very close to the distribution for Colander's initial study. The comparison group's data of top schools come from Colander's previous study of top schools [Colander 2006].

\section{PROFILE OF THE MEDIAN STUDENT}

The median economics student is a white, 28-year-old, male, making him about 2 years older than the average student at top schools. At median programs, women made up 37 percent of our respondents, a slightly higher percentage than the 29 percent in Colander's study of top schools. The ethnic composition of respondents is very similar across rankings. There are, however, fewer foreign student respondents in the median school survey than at top schools: 47 percent of median respondents are foreign compared with 62 percent in top schools. Median students were also less likely to have majored in economics or math at the undergraduate level. A total of 67 percent of median students hold undergraduate degrees in economics, and 8 percent in mathematics, compared with 81 and 21 percent, respectively, for those attending top programs. Fewer median students obtained a Masters degree before pursuing their doctorate. Half of all median students worked before entering graduate school, a similar result to top students. However, there was a difference in the type of work they did. Students at top programs are more likely to have worked as economics research assistants, whereas median students were more likely to have had non-economics related work.

The median student body is not homogeneous regarding the factors that influenced their graduate program choice, and includes two distinct subgroups: US students and non-US students. US students in median programs are more likely to have chosen their program because of its geographical location. A total of 43 percent 
said they chose it because it was geographically where they wanted to be; only 26 percent of non-US students choose it for that reason. Non-US students were much more likely to have chosen the program because it was the most highly ranked program they were accepted at; 28 percent of non-US students chose it for that reason, compared with 14 percent of US students.

Economists are often thought of as conservative, but that is not the case for graduate students in either median or top schools. Specifically, 31 percent of median students classified themselves as moderate, 36 percent as liberal, 12 percent as conservative, and 3 percent as radical. This compares to 24 percent moderate, 47 percent liberal, 16 percent conservative, and 6 percent radical at the top schools. Median programs also have a relatively high percentage of students expressing no interest in politics compared with top programs. A total of 17 percent of median students vs 6 percent of students at top schools had no interest in politics. About one in five students at median programs said that their political views had changed in graduate school, the majority of which became more moderate.

Table 1 indicates the percentage of students who expressed "great interest" in specific fields of study. A few notable differences across school categories stand out. The largest difference is in econometrics, where the median student is almost twice as likely to express great interest compared with students at top schools. Furthermore, the median student expresses greater interest in most fields of study. The area of greatest interest to median students is microtheory; women at top schools in particular have a much lower interest in microtheory. It is also interesting to note that women at top schools show much more interest in labor economics than do men, but show significantly less interest in money and banking. For both groups, the area of least interest is comparative systems, followed closely by history of thought and urban economics.

As indicated in Table 2, which breaks down the results on interest at the median school by year, student interest in fields fluctuated by year, and generally declined as students progressed. It seems that by the fifth year and beyond student's general

Table 1 Fields "of Great Interest" by school rank and gender ${ }^{\mathrm{a}}$

\begin{tabular}{|c|c|c|c|c|c|c|}
\hline & \multicolumn{3}{|c|}{ Median (\%) } & \multicolumn{3}{|c|}{ Top (\%) } \\
\hline & Total & Female & Male & Total & Female & Male \\
\hline Microtheory & 46 & 45 & 47 & 35 & 18 & 42 \\
\hline Macrotheory & 31 & 29 & 33 & 34 & 29 & 35 \\
\hline Econometrics & 40 & 41 & 40 & 22 & 14 & 26 \\
\hline International trade & 28 & 32 & 25 & 19 & 23 & 18 \\
\hline Public finance & 26 & 25 & 26 & 24 & 28 & 23 \\
\hline Money and banking & 22 & 20 & 24 & 21 & 12 & 25 \\
\hline Labor & 26 & 32 & 23 & 32 & 42 & 28 \\
\hline Industrial organization & 29 & 30 & 28 & 18 & 18 & 18 \\
\hline Law and economics & 24 & 23 & 25 & 15 & 11 & 17 \\
\hline Urban economics & 15 & 16 & 15 & 11 & 17 & 9 \\
\hline Economic development & 39 & 43 & 37 & 39 & 40 & 38 \\
\hline Comparative economic systems & 14 & 14 & 14 & 9 & 9 & 9 \\
\hline History of thought & 17 & 17 & 17 & 9 & 5 & 11 \\
\hline Political economics & 32 & 28 & 35 & 24 & 18 & 27 \\
\hline
\end{tabular}

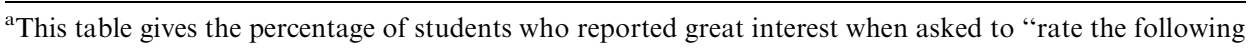
fields with respect to your degree of interest." 
Table 2 Fields "of Great Interest" to students at median schools by year

\begin{tabular}{lccccc}
\hline & $\begin{array}{c}\text { Year } 1 \\
(\%)\end{array}$ & $\begin{array}{c}\text { Year } 2 \\
(\%)\end{array}$ & $\begin{array}{c}\text { Year } 3 \\
(\%)\end{array}$ & $\begin{array}{c}\text { Year } 4 \\
(\%)\end{array}$ & $\begin{array}{c}\text { Year 5+ } \\
(\%)\end{array}$ \\
\hline Microtheory & 49 & 45 & 41 & 52 & 23 \\
Macrotheory & 34 & 29 & 32 & 27 & 16 \\
Econometrics & 30 & 48 & 37 & 39 & 26 \\
International trade & 37 & 27 & 27 & 19 & 11 \\
Public finance & 28 & 33 & 19 & 19 & 12 \\
Money and banking & 22 & 31 & 16 & 19 & 8 \\
Labor & 21 & 20 & 27 & 34 & 16 \\
Industrial organization & 31 & 24 & 27 & 27 & 20 \\
Law and economics & 29 & 25 & 18 & 21 & 11 \\
Urban economics & 19 & 15 & 12 & 12 & 7 \\
Economic development & 49 & 40 & 29 & 34 & 20 \\
Comparative economic systems & 19 & 13 & 11 & 6 & 10 \\
History of thought & 22 & 17 & 11 & 15 & 8 \\
Political economics & 43 & 28 & 28 & 27 & 14 \\
\hline
\end{tabular}

Table 3 Other activities ${ }^{\mathrm{a}}$

\begin{tabular}{lccccccc}
\hline & \multicolumn{9}{c}{ Median $(\%)$} & \multirow{2}{*}{ Top $(\%)$} \\
\cline { 2 - 6 } & Total & 1 st & 2nd & 3rd & 4 th & 5 th + & \\
\hline TA & 54 & 45 & 50 & 68 & 65 & 54 & 37 \\
RA & 30 & 21 & 34 & 35 & 32 & 31 & 31 \\
Writing scholarly papers & 31 & 11 & 19 & 38 & 53 & 53 & 49 \\
Sports & 24 & 21 & 24 & 25 & 29 & 22 & 33 \\
Volunteerism & 14 & 13 & 16 & 15 & 15 & 11 & 13 \\
Consulting & 9 & 6 & 12 & 8 & 6 & 12 & 8 \\
Political work & 2 & 1 & 3 & 2 & 4 & 2 & 4 \\
\hline
\end{tabular}

${ }^{a}$ This table reports answers to the question "In which of the following activities, besides studying, are you currently engaged. Check all applicable alternatives."

interest in the various areas has declined markedly. Students were also asked about activities they were engaged in outside of class work. Table 3 provides the overall responses (as well as responses by year in the program) and compares these with those of students at top programs.

Median students are more likely to hold teaching assistantships than top students, especially during latter years in their program. This, we suspect, is related to the lesser research-oriented financial support offered by median programs. A second difference is that fewer median students are engaged in the writing of scholarly papers. Whereas 49 percent of students in top programs spend some of their time writing scholarly papers for publication, only 31 percent of median students are similarly engaged. We suspect this reflects both the strong push at top schools to get students writing papers early (since it is often expected that if you are going to get a job at a top university, you should have one or two papers submitted for publication at the time you apply) and the need of median programs to have graduate students working as TA's. As will be discussed in more detail below, the median student is less focused on getting a job at a top university.

Table 4 compares median students' answers to what puts a student on the fast track to the responses of students at top programs. 
Table 4 What puts students on the fast track ${ }^{\mathrm{a}}$

\begin{tabular}{|c|c|c|c|c|c|c|c|c|}
\hline & \multicolumn{2}{|c|}{$\begin{array}{c}\text { Very important } \\
(\%)\end{array}$} & \multicolumn{2}{|c|}{$\begin{array}{c}\text { Moderately } \\
\text { important }(\%)\end{array}$} & \multicolumn{2}{|c|}{$\begin{array}{l}\text { Unimportant } \\
(\%)\end{array}$} & \multicolumn{2}{|c|}{$\begin{array}{c}\text { Don't know } \\
(\%)\end{array}$} \\
\hline & Median & Top & Median & Top & Median & Top & Median & Top \\
\hline $\begin{array}{l}\text { Being smart in the sense that } \\
\text { they are good at problem } \\
\text { solving }\end{array}$ & 60 & 51 & 35 & 38 & 3 & 7 & 1 & 2 \\
\hline $\begin{array}{l}\text { Being interested in, and good } \\
\text { at, empirical research }\end{array}$ & 55 & 30 & 38 & 52 & 5 & 12 & 2 & 4 \\
\hline Excellence in mathematics & 54 & 30 & 41 & 52 & 4 & 14 & 1 & 3 \\
\hline $\begin{array}{l}\text { Being very knowledgeable } \\
\text { about one particular field }\end{array}$ & 34 & 35 & 46 & 42 & 16 & 15 & 4 & 7 \\
\hline $\begin{array}{l}\text { Ability to make connections } \\
\text { with prominent professors }\end{array}$ & 39 & 33 & 44 & 40 & 13 & 19 & 4 & 7 \\
\hline $\begin{array}{l}\text { A broad knowledge of the } \\
\text { economics literature }\end{array}$ & 24 & 11 & 52 & 44 & 21 & 35 & 3 & 8 \\
\hline $\begin{array}{l}\text { A thorough knowledge of } \\
\text { the economy }\end{array}$ & 20 & 9 & 44 & 24 & 33 & 51 & 4 & 15 \\
\hline
\end{tabular}


the fast track?" Students were free to interpret the question in any way they wanted, and may have interpreted it as either referring to program success or professional success.

Median students consider empirical research and excellence in mathematics to be much more important than do students at top schools. Our belief is that these differences reflect, in part, the better mathematical training of students at top schools, and the difference in focus. Such skills are more likely to be taken for granted by students at top schools than those at median schools. In interviews conducted at top schools by Colander [2006], it was clear that creativity - telling the professor something they did not already know - was seen by students as the path to the fast track, and this need not be closely related to excellence in mathematics or even in empirical research.

Another difference between median and top school responses is that median students reported knowledge of the economy and of economics literature as more important than did students in top programs. This most likely reflects both the training and the type of job students are likely to get. Graduates from top schools are more likely to be preparing for a job at a major university, where research dominates, and much of that research is highly abstract and specialized, and generally removed from a broad knowledge of the literature or real-world economy. Median students are more likely to be preparing for an undergraduate teaching position or a job in government or private business where knowledge of literature and the economy is more highly valued.

Table 5 presents the answers to a question asking the degree of stress generated by different components to their program. Other than a student's financial situation, there are only slight differences between students at the two categories of institutions. As to be expected, more than one-half of each cohort indicated that coursework and finding a dissertation topic was either stressful or very stressful.

Despite the degree of stress experienced, students at median programs were happy with their experience in graduate economics, although not as happy as those at top schools. Three quarters of all median students indicated that they would attend graduate school if they had to do it over again, compared with 93 percent of students 
Table 5 Elements of stress ${ }^{\mathrm{a}}$

\begin{tabular}{|c|c|c|c|c|c|c|c|c|}
\hline & \multicolumn{2}{|c|}{$\begin{array}{c}\text { Very stressful } \\
(\%)\end{array}$} & \multicolumn{2}{|c|}{$\begin{array}{l}\text { Stressful } \\
(\%)\end{array}$} & \multicolumn{2}{|c|}{$\begin{array}{c}\text { Moderately } \\
\text { stressful }(\%)\end{array}$} & \multicolumn{2}{|c|}{$\begin{array}{c}\text { Not stressful } \\
(\%)\end{array}$} \\
\hline & Median & Top & Median & Top & Median & Top & Median & Top \\
\hline Coursework & 27 & 33 & 35 & 32 & 28 & 26 & 10 & 9 \\
\hline Your financial situation & 20 & 8 & 20 & 12 & 34 & 33 & 26 & 47 \\
\hline Relationship with faculty & 8 & 9 & 14 & 24 & 28 & 34 & 50 & 33 \\
\hline Relationship with students & 2 & 1 & 6 & 10 & 19 & 25 & 73 & 64 \\
\hline Doing the mathematics & 16 & 12 & 22 & 21 & 36 & 31 & 27 & 36 \\
\hline Finding a dissertation topic & 22 & 29 & 31 & 33 & 27 & 20 & 19 & 18 \\
\hline $\begin{array}{l}\text { Maintaining a meaningful life } \\
\text { outside school }\end{array}$ & 21 & 22 & 25 & 23 & 28 & 30 & 26 & 26 \\
\hline $\begin{array}{l}\text { Conflict between course } \\
\text { content and your interests }\end{array}$ & 16 & 16 & 25 & 18 & 33 & 34 & 27 & 32 \\
\hline
\end{tabular}

aThis table reports responses to the question: "Can you think of any elements of graduate school that have been, or are currently, stressful for you." It gave students the eight options listed to choose from.

Table 6 Current $v s$ prior perspectives on economics ${ }^{\mathrm{a}}$

\begin{tabular}{|c|c|c|c|c|c|c|c|c|}
\hline & \multicolumn{2}{|c|}{$\begin{array}{c}\text { Currently agree } \\
(\%)\end{array}$} & \multicolumn{2}{|c|}{$\begin{array}{c}\text { Previously } \\
\text { agreed }(\%)\end{array}$} & \multicolumn{2}{|c|}{$\begin{array}{c}\text { Currently } \\
\text { disagree }(\%)\end{array}$} & \multicolumn{2}{|c|}{$\begin{array}{c}\text { Previously } \\
\text { disagreed }(\%)\end{array}$} \\
\hline & Median & Top & Median & Top & Median & Top & Median & Top \\
\hline $\begin{array}{l}\text { The study of economics is } \\
\text { relevant for the economic } \\
\text { problems of today }\end{array}$ & 58 & 44 & 67 & 37 & 7 & 5 & 3 & 10 \\
\hline $\begin{array}{l}\text { Economists agree on the } \\
\text { fundamental issues }\end{array}$ & 8 & 9 & 18 & 11 & 45 & 44 & 30 & 34 \\
\hline $\begin{array}{l}\text { We can draw a sharp line } \\
\text { between positive and } \\
\text { normative economics }\end{array}$ & 12 & 12 & 17 & 15 & 35 & 40 & 22 & 28 \\
\hline $\begin{array}{l}\text { Learning mainstream } \\
\text { economics means learning } \\
\text { a set of tools }\end{array}$ & 45 & 36 & 31 & 26 & 13 & 14 & 15 & 13 \\
\hline $\begin{array}{l}\text { Economics is the most scientific } \\
\text { discipline among the social } \\
\text { sciences }\end{array}$ & 51 & 50 & 46 & 46 & 14 & 16 & 13 & 15 \\
\hline
\end{tabular}

${ }^{\text {a This question asked students to "consider the following statements and compare your current opinion }}$ with the one you held before you began graduate school." It provided students four options: strongly agree, agree somewhat, disagree, and no clear opinion. Results report in this table combine the strongly agree and agree somewhat responses into the category of agree.

at top schools. Students at median schools were also slightly less happy with the experience in their particular program than were students at top schools. Only 56 percent of students at median programs said they would attend the same graduate school compared with more than 80 percent at top schools.

Table 6 presents current views of students on a number of propositions about economics, and contrasts them with those they held prior to entering graduate school.

Graduate school study appears to have had the greatest impact on their perception that learning mainstream economics means learning a set of tools; 
Table 7 Views on policy issues ${ }^{\mathrm{a}}$

\begin{tabular}{|c|c|c|c|c|c|c|c|c|}
\hline & \multicolumn{2}{|c|}{$\begin{array}{l}\text { Agree } \\
(\%)\end{array}$} & \multicolumn{2}{|c|}{$\begin{array}{l}\text { Agree with } \\
\text { reservations }(\%)\end{array}$} & \multicolumn{2}{|c|}{$\begin{array}{l}\text { Disagree } \\
(\%)\end{array}$} & \multicolumn{2}{|c|}{$\begin{array}{c}\text { I have no opinion } \\
(\%)\end{array}$} \\
\hline & Median & Top & Median & Top & Median & Top & Median & Top \\
\hline $\begin{array}{l}\text { Fiscal policy can be an effective } \\
\text { tool in a stabilization policy }\end{array}$ & 23 & 21 & 55 & 58 & 13 & 12 & 9 & 9 \\
\hline $\begin{array}{l}\text { Central banks should maintain } \\
\text { a constant growth of the } \\
\text { money supply }\end{array}$ & 10 & 7 & 38 & 22 & 33 & 50 & 19 & 22 \\
\hline $\begin{array}{l}\text { The distribution of income in } \\
\text { developed nations should be } \\
\text { more equal }\end{array}$ & 25 & 32 & 33 & 41 & 33 & 18 & 8 & 9 \\
\hline $\begin{array}{l}\text { A minimum wage increases } \\
\text { unemployment among young } \\
\text { and unskilled workers }\end{array}$ & 31 & 33 & 34 & 38 & 28 & 23 & 7 & 7 \\
\hline $\begin{array}{l}\text { Tariffs and import quotas } \\
\text { reduce general economic } \\
\text { welfare }\end{array}$ & 47 & 51 & 37 & 39 & 12 & 7 & 5 & 3 \\
\hline $\begin{array}{l}\text { Inflation is primarily a } \\
\text { monetary phenomenon }\end{array}$ & 27 & 34 & 36 & 33 & 23 & 20 & 14 & 14 \\
\hline $\begin{array}{l}\text { Wage-price controls should } \\
\text { be used to control inflation }\end{array}$ & 4 & 0 & 18 & 8 & 61 & 78 & 17 & 13 \\
\hline $\begin{array}{l}\text { Worker democracy will } \\
\text { increase labor productivity }\end{array}$ & 10 & 10 & 33 & 29 & 26 & 29 & 31 & 32 \\
\hline $\begin{array}{l}\text { The market system tends to } \\
\text { discriminate against women }\end{array}$ & 15 & 14 & 31 & 28 & 42 & 47 & 11 & 11 \\
\hline $\begin{array}{l}\text { The capitalist system has an } \\
\text { inherent tendency towards } \\
\text { crisis }\end{array}$ & 9 & 6 & 19 & 12 & 56 & 68 & 16 & 14 \\
\hline
\end{tabular}

${ }^{\text {a }}$ This question asked students whether they agreed with the following propositions, providing the four answer options listed in the table.

45 percent of median students now strongly agree with this proposition as compared with only 31 percent holding that belief prior to graduate school. Median students also became more skeptical of the view that economists agree on the fundamental issues; disagreement with the statement grew from 30 percent of all students prior to entry in the program to 45 percent at the time of the survey. Students' views on other statements did not change to a large degree. When comparing the median student responses to those at top schools, only minor differences exist with the exception of the "relevance" of economic study. ${ }^{5}$

In Table 7, we compare median and top students' views on policy issues. What stands out in this table is the similarity of views.

There were a few small differences, however. For example, median students were slightly more likely to agree with the proposition that central banks should maintain a constant growth of the money supply, and were slightly less likely to agree that the distribution of income in developed natures should be more equal. For the most part however, there was not a strong difference in views. Table 8 reports the importance of certain assumptions for economics analysis as perceived by students in each cohort. The assumptions for which students were least likely to have an opinion were "cost mark-up pricing" and "the goal of a capitalist firm is to extract surplus value from workers." Approximately, 20 percent of median students had no strong 
Table 8 Views on economic assumptions ${ }^{\mathrm{a}}$

\begin{tabular}{|c|c|c|c|c|c|c|c|c|}
\hline & \multicolumn{2}{|c|}{$\begin{array}{c}\text { Very important } \\
(\%)\end{array}$} & \multicolumn{2}{|c|}{$\begin{array}{c}\text { Important in } \\
\text { some cases }(\%)\end{array}$} & \multicolumn{2}{|c|}{$\begin{array}{c}\text { Unimportant } \\
(\%)\end{array}$} & \multicolumn{2}{|c|}{$\begin{array}{c}\text { I have no strong } \\
\text { opinion }(\%)\end{array}$} \\
\hline & Median & Top & Median & Top & Median & Top & Median & Top \\
\hline The assumption of rational behavior ${ }^{b}$ & 58 & 51 & 36 & 43 & 5 & 5 & 1 & 1 \\
\hline $\begin{array}{l}\text { Economic behavior according to } \\
\text { conventions }\end{array}$ & 12 & 9 & 58 & 55 & 15 & 17 & 15 & 19 \\
\hline The rational expectations hypothesis & 31 & 25 & 51 & 58 & 10 & 13 & 7 & 4 \\
\hline Imperfect competition & 46 & 37 & 47 & 58 & 3 & 3 & 4 & 2 \\
\hline Price rigidities & 24 & 14 & 56 & 65 & 9 & 11 & 12 & 10 \\
\hline Cost mark-up pricing & 15 & 5 & 51 & 47 & 10 & 18 & 24 & 30 \\
\hline $\begin{array}{l}\text { The goal of a capitalist firm is to } \\
\text { extract surplus value from workers }\end{array}$ & 14 & 5 & 34 & 23 & 32 & 55 & 20 & 17 \\
\hline
\end{tabular}

${ }^{a}$ This table reports answers to the question: "How important do you consider the following assumptions or perspectives for economic analysis."

'In the survey of top schools, this assumption was phrased as the "neoclassical" assumption of rational behavior.

opinion on either assumption. Yet for those who did have an opinion on the assumption "the goal of a capitalist firm is to extract surplus value from workers," a dramatic difference across cohorts exists. A total of 48 percent of all median students thought the assumption to be of some importance, whereas only 28 percent of students in top programs thought this to be important for economic analysis. This could signify that median students have greater exposure to more heterodox teachings of economics than students at top schools, despite the fact that schools most associated with radical and Marxist thought were excluded from the survey (see footnote 3 ).

A few other responses are worth reporting. When asked to evaluate the relevance of economists in society, 78 percent of median students answered positively. Only 5 percent thought economists to be irrelevant and 16 percent were unsure. Students at top tier programs responded exactly the same way. When asked how often they used economic thinking, 77 percent of the students at median programs said they used it very often. Both of these are very similar to the responses of students at top schools. Another survey question asked students to identify their future employment plans - specifically where they hoped to be in 15 years. Here there was a difference with students at top programs. Whereas 59 percent of top students saw themselves at a major university, only 27 percent of median students envisioned themselves there. Alternatively, 18 percent of median students saw themselves at good liberal arts colleges compared with 9 percent of students at top schools.

\section{DISCUSSION OF RESULTS}

We did this study as a follow up to Colander's earlier studies, and it confirmed our prior view that students at median programs have similar attitudes to those at top programs. We hope to use it as a beginning of a broader comparison of top programs and median programs, in which we ask the questions: should and do median programs differ from top programs. By considering differences in student attitudes, this study provides some insights into that comparison. One difference is 
that students recognized that their likely job prospects differed. When asked whether they hoped to be at a major university in 15 years, 27 percent of the median students indicated so, compared with 59 percent of the students at top universities. Similarly, 18 percent of the median students, compared the 9 percent of the students at top universities, pictured themselves at a liberal arts college in 15 years.

Another difference that the study highlighted concerned their training. Students at median schools are more likely to hold positions as TAs and spend less time writing scholarly papers than students at top schools. Students' interpretations of the importance of specific educational components also differ. Students at median schools give greater importance to knowledge of literature and knowledge of the economy than students do at top schools. Similarly, in terms of skills important to career advancement, students at median programs gave much higher weight to empirical research than their top tier counterparts. All these results suggest to us that the median schools differ from the top schools in the training they provide, with the training at median schools better suited to the likely jobs that median students will be getting.

Another result suggested that the changes were not as large as might be expected. Specifically, since excellence in mathematics is more likely to be of importance to students going on into graduate research, we would have expected students at median schools to downplay its importance. That, however, was not the case. Students at median programs gave much more weight to excellence in mathematics (54 percent) than students in top tier schools (30 percent). There are a number of possible explanations for this result. One is that median programs often hire their professors from top programs which focus on mathematics and technical issues relevant for high-level scientific research much more than on the institutional, contextual, and more practical statistical issues that are more relevant for the teaching and applied policy research jobs that students in median programs will likely obtain. Professors teach what they learned. This tendency to copy the top programs in what is taught is reinforced by the tenure and promotion system since almost all median programs structure their research incentives using the same quality-weighted journal article metric that emphasizes high-level scientific research that the top schools tend to use, rather than using a metric that more closely matches the skills median students will need. It was this approach as revealed in the COGEE Commission study that led to the suggestion that there should be more differentiation in the training of graduate students [Krueger et al. 1991]. Such issues, however, are beyond the scope of this paper. But we hope the paper will generate interest into other looking into whether there is sufficient differentiation between top and median programs.

\section{Notes}

1. Colander's initial survey is available in Colander [2006]. Here we provide relevant questions in footnotes where appropriate.

2. In 2005, 11,805 students were enrolled in economics graduate programs granting masters and/or Ph.D.s [NSF 2005], which is a slightly larger group than those granting Ph.D.s, the group we tried to capture.

3. We also excluded five schools that might be called heterodox programs, the New School, University of Massachusetts Amherst, George Mason University, University of Utah and University of Missouri in Kansas City. These programs were sufficient outliers so that we felt that they were best considered separately.

4. In choosing the subset we tried to exclude those programs that had only Masters Programs and thus only capture students in Ph.D. programs. There are a couple potentials for bias that parallel the bias in 
Colander's earlier studies. Specifically, technically oriented students and foreign students are less likely to answer questionnaires, so the estimates of foreign students may be low, and the answers may reflect the views of less technically oriented students. While we tried to find an appropriate sample, the study makes no claim to be a fully scientific study. Thus, like Colander's earlier studies no significance tests are reported since the assumptions needed for the significance tests to be significant have not been met, and including such test statistics could make the results more scientific than they in fact are.

5. This difference might be attributable to a change in wording. The survey of top students [Colander 2006] specified "neoclassical economics." Because the term "neoclassical" proved ambiguous to many students - they did not know what it meant, in this study we specified "economics" rather than neoclassical economics.

\section{References}

Colander, David. 2005. The Making of an Economist Redux. Journal of Economic Perspectives, 19(1): $175-198$.

2006. The Making of an Economist Redux. Princeton, NJ: Princeton University Press.

Colander, David, and Arjo Klamer. 1987. The Making of an Economist. Journal of Economic Perspectives, 1(2): 95-111.

Hansen, W. Lee. 1991. The Education and Training of Economics Doctorates: Major Findings of the Executive Secretary of the American Economic Association's Commission on Graduate Education in Economics. Journal of Economic Literature, 29(3): 1054-1087.

Krueger O. Anne, Kenneth J. Arrow, Olivier Jean Blanchard, Alan S. Blinder, Claudia Goldin, Edward E. Learner, Robert Lucas, John Panzar, Rudolph G. Penner, T. Paul Schultz, Joseph E. Stiglitz, and Lawrence H. Summers. 1991. Report of the Commission of Graduate Education in Economics. Journal of Economic Literature, 29(3): 1035-1053.

National Science Foundation. 2005. http:/www.nsf.gov/statistics/nsf07321/pdf/tab10.pdf.

Scott, Frank A. Jr., and Jeffrey D. Anstine. 1997. Market Structure in the Production of Economics Ph.D'S. Southern Economic Journal 64(1): 307-320.

Thursby, J.G. 2000. What Do We Say about Ourselves and What Does It Mean? Yet Another Look at Economics Department Research. Journal of Economic Literature, 38(2): 383-404. 